\title{
Erratum to: Conclusions
}

\author{
Robert C. Brears
}

\section{Erratum to:}

Chapter 8 in: Robert C. Brears, Climate Resilient Water Resources Management, DOI 10.1007/978-3-319-78896-8_8

Authors, Charles Breen and Machaya Chomba, were inadvertently added as Chapter authors for the conclusion Chapter. Hence, they were removed and Robert C. Brears is the sole author of the chapter.

The updated original online version for this chapter can be found at https://doi.org/10.1007/978-3-319-78896-8_8

R. C. Brears $(*)$

Our Future Water, Christchurch, New Zealand

R. C. Brears (ed.), Climate Resilient Water Resources Management, Palgrave Studies in Climate Resilient Societies, https://doi.org/10.1007/978-3-319-78896-8_9 